\title{
MORPHOLOGY OF THE ADRENAL GLANDS OF GIANT ANTEATER (Myrmecophaga tridactyla, LINNAEUS, 1758) OF WILD LIFE
}

\author{
MORFOLOGIA DAS GLÂNDULAS ADRENAIS DE TAMANDUÁ-BANDEIRA \\ (Myrmecophaga tridactyla, LINNAEUS, 1758) DE VIDA LIVRE
}

\section{Amilton Cesar dos SANTOS ${ }^{1}$; Diego Carvalho VIANA ${ }^{1}$; Rafael Magdanelo LEANDRO²; Rosângela Felipe RODRIGUES ${ }^{3}$; Antônio Chaves de ASSIS-NETO²; Alan Peres Ferraz de MELO ${ }^{3}$}

1. Doutorando, Faculdade de Medicina Veterinária e Zootecnia- FMVZ, Universidade de São Paulo-USP, São Paulo, SP, Brasil. amiltonsantoss@usp.br; 2. Professores Doutores, Faculdade de Medicina Veterinária e Zootecnia - FMVZ, Universidade de São PauloUSP, São Paulo, SP, Brasil; 3. Professores Doutores. Faculdade de Engenharia, Universidade Estadual Paulista-UNESP, Campus de Ilha Solteira, SP, Brasil.

\begin{abstract}
The Myrmecophaga tridactyla (family Pilosa), popularly known in Brazil as the giant anteater is classified as an endangered species by the main survey agencies of biodiversity preservation around the world. The adrenal glands are important organs, which are related to homeostasis of the animal. This study aimed to describe the morphology of the adrenal glands of $M$. tridactyla, providing data for future studies related to the production of steroid hormones in specimens exposed to different stress factors. The adrenal glands of 14 specimens were used. The glands were measured, photodocumented and described by light microscopy. The adrenals were positioned in the cranial extremity of the kidneys (left and right) and related medially to the caudal vena cava. The right adrenal gland had an elongated shape while the left adrenal gland had pyramidal or triangular shape. The weight was $4.765 \pm 0.129 \mathrm{~g}$ for the right adrenal and $3.975 \pm 0.213 \mathrm{~g}$ for the left adrenal. The length was $4.50 \pm 0.14 \mathrm{~cm}$ for the right adrenal and $4.28 \pm 0.11 \mathrm{~cm}$ for the left adrenal. The width was $2.60 \pm 0.13 \mathrm{~cm}$ for the right adrenal and $2.37 \pm 0.12 \mathrm{~cm}$ for the left adrenal. The thickness was $0.45 \pm 0.11 \mathrm{~cm}$ for the right adrenal and $0.68 \pm 0.14 \mathrm{~cm}$ for the left adrenal. Statistical differences $(\mathrm{p}<0.05)$ between right and left adrenals for all values analyzed were observed. Microscopically it was observed a capsule composed by modeled dense connective tissue lining the organ. Below this capsule, from the outermost to the innermost layer, it was observed a cortical region divided into glomerular, fasciculata and reticular zones with a medullar region occupying the center of the organ. Further studies related to steroidogenesis with specimens collected at different periods of the year are necessary, aiming to observe if there are morphological or hormonal variations in the adrenal glands due to seasonal periods. This information would be of great importance because it could reflect the behavioral habits of this species.
\end{abstract}

KEYWORDS: Endangered species. Fasciculata zone. Glomerular zone. Reticular zone.

\section{INTRODUCTION}

The Myrmecophaga tridactyla are mammals that live at the Cerrado biome (CUNHA et al., 2015) and are popularly known in Brazil as the Giant Anteater (ROSA et al., 2012). They are members of Superorder Xenarthra belonging to family Pilosa (SANCHEZ et al., 2013), previously described as family Mymercophagidae (SHAW; MCDONALD, 1987; ROSSI et al., 2012). This family of mammals constitute an important conservation group, because is highly vulnerable, according to Brazilian Official List of Species Threatened with Extinction (CRUZ et al., 2013; IBAMA, 2016) and "near threatened" in Red List of the International Union for Conservation of Nature (ROSSI et al., 2012; CRUZ et al., 2013; IUCN, 2015) and since 2003 is included in the Appendix II of the Convention on International Trade in Endangered Species (SANCHES et al., 2013). Although in recent years, M. tridactyla is threatened with extinction, it had a much wider geographical distribution in past times, inhabiting even other sub-continents, such as North America according to the discovery of fossil records (SHAW; MCDONALD, 1987).

The adrenal glands can undergo adjustment due to various stress factors (PARKER et al., 2011). In mammals, each adrenal gland is composed of two structures: the cortex, which is originated from embryonic mesoderm and the medulla, which is originated from embryonic neurectoderm. Each part of the adrenal gland has different cell types: the cortex cells produce mineralocorticoid, glucocorticoids and sexual steroid hormones (SANTOS et al., 2016) while in the medulla, chromaffin cells produce catecholamine and neuropeptides (KEMPNÁ; FLÜCK, 2008; QIU et al., 2012).

Due to the importance of the adrenal glands to the homeostasis of animals, especially those exposed to large amounts of stress factors, this study aimed to describe for the first time, the macroscopic 
and microscopic anatomy of the adrenal glands in M. tridactyla, providing data for future studies related to the production of steroid hormones in these glands.

\section{MATERIAL AND METHODS}

In the present study, adrenal glands from 14 specimens of $M$. tridactyla were studied. All specimens were collected at the SACCAS (Sector of Clinical and Surgical Attendance of Wild Animals) of the Veterinary Hospital "Dr. Halim Atique", responsible for providing support for Environmental Military Police of São Paulo and IBAMA Brazilian Institute of Environment and Renewable Natural Resources. The research was duly approved by the Bioethics Committee of the School of Veterinary Medicine and Animal Science of the University of São Paulo with the protocol number 3016/2013.

The adrenal glands were photodocumented in situ for topographical description of the organ. Then, adrenals were weighted using a precision scale (Slim ${ }^{\circledR}$ high precision) and measured by Mitotuyo ${ }^{\circledR}$ precision calipers to perform comparison between the glands of the right and left antimeres. The analysis of variance using the GraphPad InStat program to obtain the mean and standard deviation was performed. Cramer-von Mises test for normality checked homoscedasticity between the variables; Tukey comparison average test provided morphometric rates. Biometrics variables are unstable $(\mathrm{CV} \leq 15 \%)$ at significance $\mathrm{p}<0.05$.

Adrenal glands were sectioned in the sagittal plane, and the hemi-adrenal glands were fixed in $10 \%$ formaldehyde solution for microscopic analysis, looking for morphological differences between left and right adrenals and distinct regions of the gland. Subsequently, the glands were dehydrated in increasing concentrations (from 50\% to $100 \%$ ) of ethanol and cleared in xylene for later inclusion in paraffin. Paraffin blocks were sectioned and samples with $5 \mu \mathrm{m}$ of thickness were stained with $\mathrm{H} / \mathrm{E}$ (hematoxylin/eosin). The microscopic photodocumentation was performed using photomicroscope Olympus BX61VS. The nomenclature of the anatomical structures was based on Nomina Anatomica Veterinaria (2012).

\section{RESULTS}

\section{Macroscopic analysis}

Pairs of the adrenal glands (left and right) of all specimens were positioned in the cranial extremity of the kidneys and presented syntopy. They were medially related to the caudal vena cava; with the pancreas, liver and rectum on the left antimere; and, with the duodenum and jejunum on the right antimere (Figure 1).

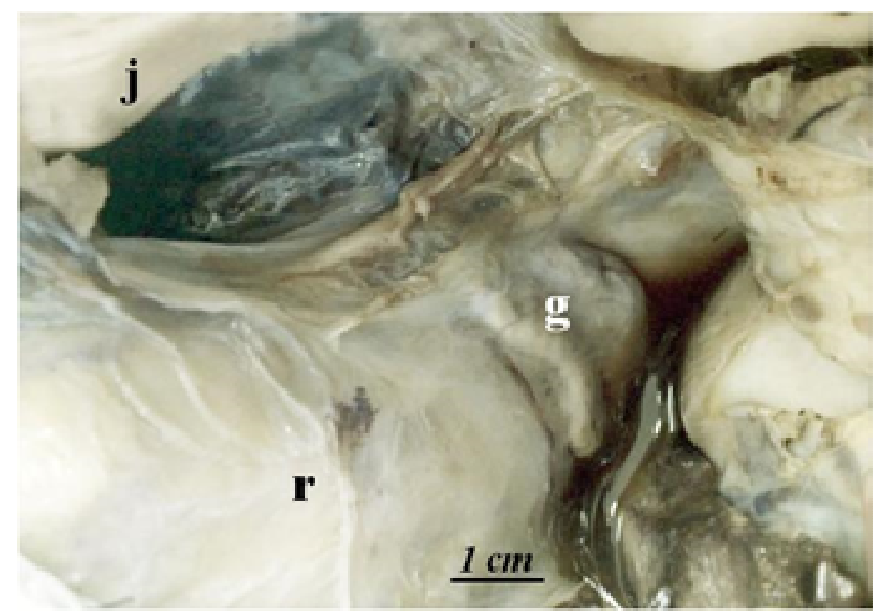

Figure 1. Image of the adrenal gland in the abdominal cavity of $M$. tridactyla. The left kidney evolved by renal capsule (r) in proximity to the left adrenal gland $(\mathrm{g})$ and the jejunum $(\mathrm{j})$. Bar: $1 \mathrm{~cm}$.

The right adrenal had an elongated shape while the left adrenal had a triangular shape. Different results regarding morphology of the right and left adrenal gland were also found for weight and all dimensions analyzed (length, width and thickness).
After the sagittal section, it was found a thick yellowish color capsule lining the organ and cortical and medullar regions with evident blood vessels in the medullar tissue. The cortex divisions were not observed macroscopically (Figure 2). 

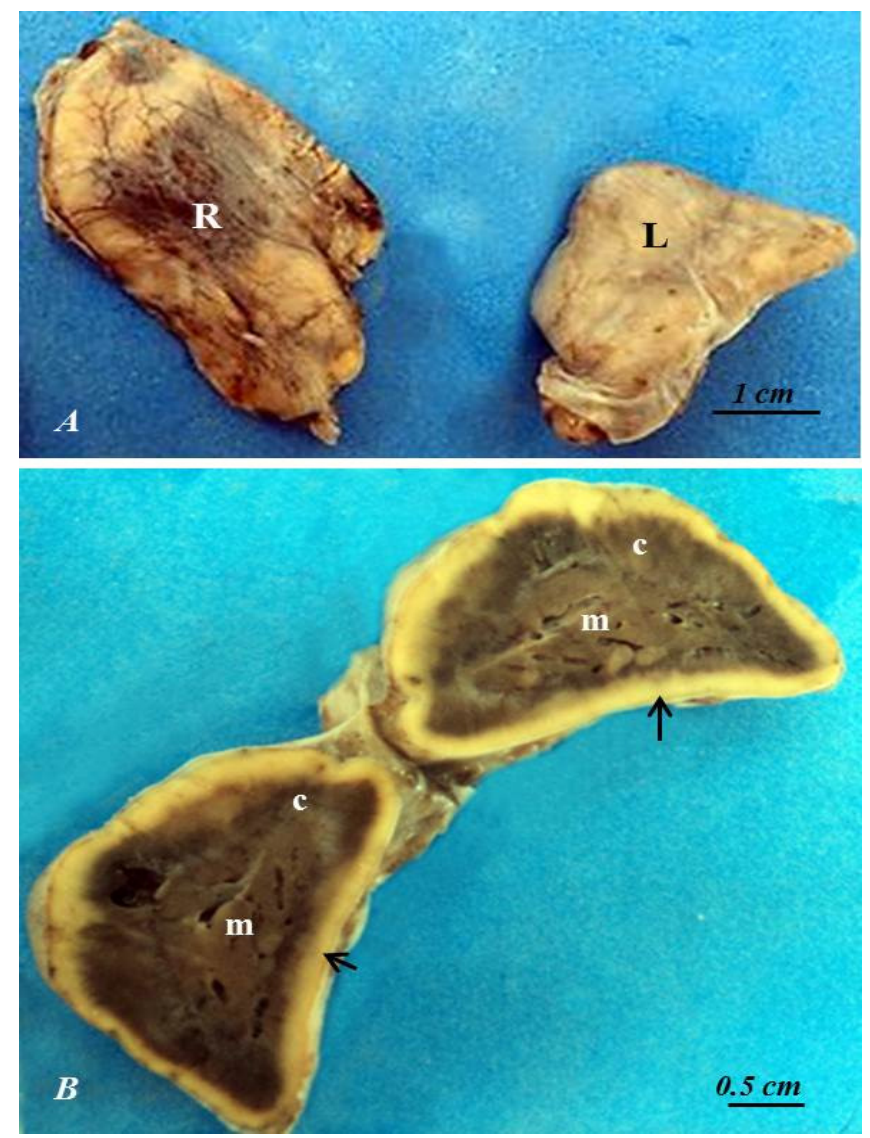

Figure 2. Image of the adrenal glands of the M. tridactyla. A: anatomical conformation of the right (R) and left (L) adrenal. Bar: $1 \mathrm{~cm}$. B: cortical region (c), medullar region $(\mathrm{m})$ and capsule (arrows) of the sectioned adrenal. Bar: $0.5 \mathrm{~cm}$.

The weight was $4.765 \pm 0.129 \mathrm{~g}$ for the right adrenal and $3.975 \pm 0.213 \mathrm{~g}$ for the left adrenal. The length was $4.50 \pm 0.14 \mathrm{~cm}$ for the right adrenal and $4.28 \pm 0.11 \mathrm{~cm}$ for the left adrenal. The width was $2.60 \pm 0.13 \mathrm{~cm}$ for the right adrenal and $2.37 \pm 0.12 \mathrm{~cm}$ for the left adrenal. The thickness was $0.45 \pm 0.11 \mathrm{~cm}$ for the right adrenal and $0.68 \pm 0.14 \mathrm{~cm}$ for the left adrenal. Statistical differences $(\mathrm{p}<0.05)$ between right and left adrenals for all values analyzed were observed.

H/E stained images showed a dense capsule composed by modeled dense connective tissue lining the organ. Below this capsule, from the outermost region to the innermost region, it was possible to observe a cortical region, divided into glomerular, fasciculata and reticular zones and a medullar region occupying the center of the organ.

The glomerular zone presented cellular clusters arranged in oval shape, while the fasciculata zone had cells arranged in cords. The reticular zone was composed of cells spread across the large amount of non-modeled dense connective tissue with presence of blood vessels. The medullary region was rich in blood vessels and chromaffin cells (Figure 3).

The tissue slices stained with Trichrome of Gomori revealed the presence of collagen fibers in the dense capsule of the organ and within the medullar region. The glomerular zone had little amount of collagen fibers and more clustered cells compared to other zones in the adrenal cortex. The fasciculata zone showed little collagen fibers. On the other hand the reticular zone showed large amount of collagen fibers (blue) and blood vessels, while the medullar region had more evident cellular nucleus when compared to cells of the fasciculata and reticular zones. At the center of the medullar region it was possible to observe a large area with collagen fibers and large blood vessels. Surrounding this area, it was possible to note an area with less collagenous fibers and an area with higher amount of these fibers (Figure 4). 


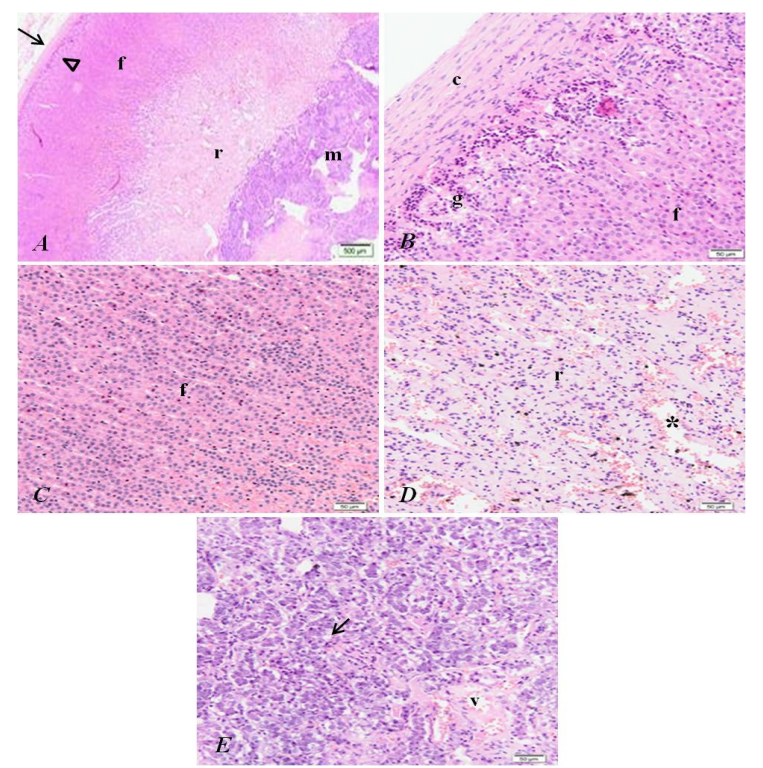

Figure 3. Photomicrograph of the adrenal gland of $M$. tridactyla stained with H/E. A: capsule (arrow); zones: glomerular (arrowhead), fasciculata (f) and reticular (r) in the cortical region; medullar region (m).



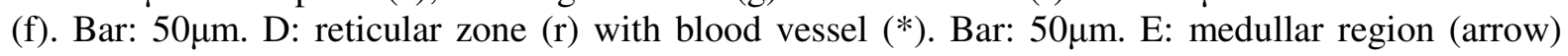
with blood vessel (V). Bar: $50 \mu \mathrm{m}$.

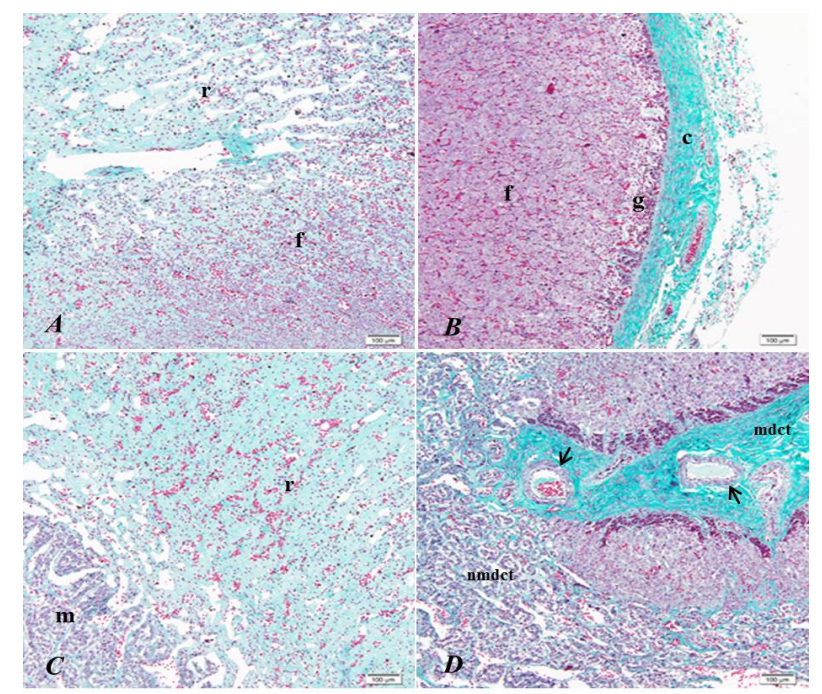

Figure 4. Photomicrograph of the adrenal gland of $M$. tridactyla stained with Trichrome of Gomori. A:

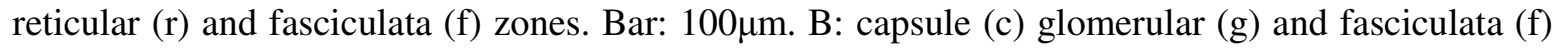

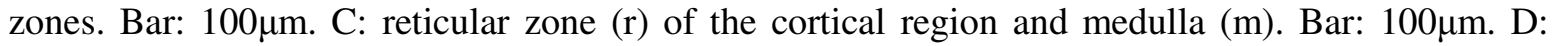
medullar region with a region rich in modeled dense connective tissue (mdct) and blood vessels with large-diameter (arrows). It was possible to observe an area with non-modeled dense connective tissue (nmdct). Bar: $100 \mu \mathrm{m}$.

\section{DISCUSSION}

The adrenal glands found in $M$. tridactyla are positioned in the cranial extremity of the kidney and related medially to the caudal vena cava. These characteristics follow the topographic location described in other wild mammals such as rodents
Lagostomus maximus (RIBES, 1999), Myocastor coypus (MACHADO et al., 2002; CULAU et al., 2008), Dasyprocta agouti (NEVES et al., 2007), Cavia porcellus (COOPER; SCHILLER, 1975) and Galea spixii (SANTOS et al., 2016), and domestic animals such as dogs, cats and horses (REECE et al., 2005). 
In current study, the adrenal glands of $M$. tridactyla with different formats and sizes when comparing right and left glands were found. The right gland had elongated shape while the left gland had triangular shape. Additionally, measurements were statistically higher $(\mathrm{p}<0.05)$ in the right glands, except for thickness. These results differ from studies by Machado et al. (2002) in Myocastor coypus and Santos et al. (2016) in Galea spixii. In this study, the authors observed asymmetry between the right and left glands. The right adrenal had triangular shape and smaller volume compared with the left gland, which had elongated shape in Galea spixii (SANTOS et al., 2016).

In this regard, with respect to morphology, anatomy and secretion products, it is known that the adrenal glands may differ between the different classes and animal species. In fishes, the chromaffin tissue and adrenocortical may be separated; in birds, these tissues are fused; the adrenal cortex of mammals is divided into zones, but the glomerulosa zone is not perceived in some of them, such as lemurs, monkeys and mice; in dogs and guinea pigs adrenocortical tissue is more abundant than chromaffin tissue (BENTLEY, 1982).

In relation to the different zones of the adrenal cortex in M. tridactyla, it was found that the first and outermost layer is the glomerular zone, located just under the capsule (consisting of connective tissue), which surrounds the organ. It has as main characteristic, the presence of cells arranged in oval groups very attached and with reduced intracellular spaces, similarly to rats (CHANG et al., 2011), Galea spixii (SANTOS et al., 2016) and Gerbilus tarabuli (SAADI; LEBAILI, 2012); the second layer is the fasciculata, characterized by columns of vacuolated cells as in rats (CHANG et al., 2011.) and Galea spixii (SANTOS et al., 2016.); and the third and last zone is the reticular, containing in its parenchyma irregular cell cords, anastomosis and randomly arrangement, similar to that found in Lagostamus maximus (RIBES et al., 1999) and Galea spixii (SANTOS et al., 2016). Below the reticular zone of the cortical region is the medullar region, which is composed of large chromaffin cells and numerous blood vessels, similar to that described in Cavia porcellus (KACZMARCZYK; KMIEC, 2004) and Galea spixii (SANTOS et al., 2016).

Regarding the division of regions of the adrenal cortex of $M$. tridactyla, it was found less evident glomerular zone in relation to fasciculata and reticular zones. Then, stereological studies in order to confirm these findings were required because the dimensions of the cortical zones could be related to different demands in the production of different steroid hormones. Hîncu et al. (2006), described that in Cavia porcellus exposed to stress, structural changes occur in the cortex due to the adaptive capacity of adrenal gland to stress factors, because initially an adaptive process is characterized by morphological and functional changes in order to life maintenance.

The adrenal glands have an important role due enzymatic mechanisms able to synthesize cholesterol and convert it into different steroid hormones, including sexual hormones (DI RIO et al., 1994; SANTOS et al., 2016); however, corticosteroids are the most important adrenal steroid hormones, both physiologically and quantitatively (Whitley et al., 1994).

Several studies have attempted to demonstrate the differentiation of the synthesis of steroid hormones in the different zones of the adrenal cortex in mammals. As example, glomerular zone synthesizes mineralocorticoid (aldosterone), the fasciculata zones produces glucocorticoids and the reticular zone produces sexual steroid hormones C19 (androgens) in humans and primates (CHANG et al., 2011), but not in rats and mice (VAN WEERDEN et al., 1992; PIGNATELLI et al., 1998; KEMPNÁ; FLÜCK, 2008). However, Shinzawa et al. (1988) in Cavia porcellus and Santos et al. (2016) in Galea spixii demonstrated that androgen production site is mainly the fasciculata zone. Already Pignatelli et al. (1998) demonstrated that in rats, the androgen production is more present in the glomerular zona than in the fasciculata zone.

Considering the difficulty to find relevant quantity of specimens for morphological studies due to vulnerability in conservation of the species as $M$. tridactyla, future studies related to steroidogenesis with specimens at different periods of the year will elucidate if the adrenal glands have seasonal variations in its morphological conformation or production of adrenal hormones resulting from these changes, and these data would be of great importance because it could reflect the behavioral habits in this species.

In conclusion, the right adrenal glands had larger measurements of weight, length and width than the left gland, however, the thickness of the right gland was lower than the left. By microscopic analysis, a modeled dense connective tissue capsule lining the organ was observed. Below this capsule, from the outermost to the innermost layer, it was possible to evidence, a cortical region, divided into glomerular, fasciculata and reticular zones and a medullar region rich in blood vessels occupying the center of the organ. 


\section{ACKNOWLEDGEMENTS}

The authors thank the Sector for Clinical Surgical Attendance (SACCAS) of the Veterinary
Hospital "Dr. Halim Atique "for the donation of animals and to Fundação de Amparo à Pesquisa do Estado de São Paulo for financial Support.

RESUMO: O Myrmecophaga tridactyla (família Pilosa), conhecido popularmente no Brasil como TamanduáBandeira, é uma espécie classificada como ameaçada de extinção pelos principais órgãos de levantamento e preservação da biodiversidade no mundo. As glândulas adrenais são importantes órgãos, relacionados com a homeostasia dos animais. Neste estudo, objetivou-se descrever a morfologia das glândulas adrenais de M. tridactyla, fornecendo dados para futuros estudos relacionados à produção de hormônios esteroides em espécimes expostos a diferentes fatores de stress. Esta pesquisa traz a análise das glândulas adrenais em 14 espécimes de $M$. tridactyla, as quais foram mensuradas, fotodocumentadas, processadas e analisadas por microscopia de luz. Encontrou-se que as glândulas adrenais pares estavam posicionadas na extremidade cranial dos rins e relacionadas medialmente com a veia cava caudal. Sendo que, a glândula adrenal direita possuía formato mais alongado que a glândula adrenal esquerda, a qual apresentou formato piramidal ou


comprimento foi de $4,50 \pm 0,14 \mathrm{~cm}$ para a glândula direita e $4,28 \pm 0,11 \mathrm{~cm}$ para a esquerda. A largura foi de $2,60 \pm 0,13 \mathrm{~cm}$ para a glândula direita e $2,37 \pm 0,12 \mathrm{~cm}$ para a esquerda. A espessura da glândula direita foi de $0,45 \pm 0,11 \mathrm{~cm}$ e da esquerda foi $0,68 \pm 0,14$. Foram observadas diferenças estatísticas $(\mathrm{p}<0,05)$ entre as glândulas direitas e esquerdas em todas as dimensões analisadas. Com auxílio de microscopia de luz observou-se uma cápsula de tecido conjuntivo denso modelado, revestindo o órgão. Abaixo dessa cápsula, foi possível evidenciar, da camada mais externa para a mais interna, uma região cortical, dividida em zonas glomerular, fasciculada e reticular, com uma região medular ocupando o centro do órgão. Futuros estudos relacionados à esteroidogênese adrenal com espécimes em diferentes épocas do ano poderiam demonstrar se as glândulas adrenais apresentam variações sazonais em sua conformação morfológica ou na produção de hormônios adrenais decorrentes dessas variações, sendo que, estes dados seriam de grande importância, pois poderiam refletir os hábitos comportamentais nesta espécie.

PALAVRAS CHAVE: Animais em risco de extinção. Tamanduá-Bandeira. Zona fasciculada. Zona glomerular. Zona reticular.

\section{REFERENCES}

BENTLEY, P. J. Comparative Vertebrate Endocrinology. 2ed. New York: Cambrigde University Press, 1982. 483p.

CHANG, S-P.; MULLINS, J. J.; MORLEY, S. D.; WEST, J. D. Transition from organogenesis to stem cell maintenance in the mouse adrenal cortex. Organogenesis. v. 7, n. 4, p. 267-280, 2011.

http://dx.doi.org/10.4161/org.7.4.18060

COOPER, G.; SCHILLER, A. L. Anatomy of the Guinea pig. Harvard University Press: Cambridge, 1975. $417 \mathrm{p}$.

CRUZ, V. S.; CARDOSO, J. R.; ARAÚJO, L. B. M.; SOUZA, P. R.; ARAÚJO, E. G. Aspectos anatômicos dos nervos da coxa de Tamanduá-Bandeira (Myrmecophaga tridactyla, Linnaeus, 1758). Bioscience Journal. v. 29, n. 5, p. 1275-1283, 2013.

CULAU, P. O. V.; AZAMBUJA, R. C.; CAMPOS, R. Ramos viscerais da artéria aorta abdominal em Myocastor coypus. Acta Scientiae Veterinarie. v. 36, n. 3, p. 241-247, 2008.

CUNHA, H. F.; CARRIJO, T. F.; PRESTES, A. C.; ARRUDA, l. S.; REZENDE, P. B.; SANTOS, T.; BRANDÃO, D. Food preference of Giant Anteater and Collared Anteater (Pilosa, Myrmecophagidae) regarding the termite defense strategies. Bioscience Journal. v. 31, n. 1, p. 234-241, 2015.

http://dx.doi.org/10.14393/BJ-v31n1a2015-23360

Di RIO, R.; BARBÉRIO, J.C.; PRADAL, M.G.; MENEZES, A.M.S. Procedimentos Hormonais. 3ed. São Paulo: CPD CRIESP, 1994. 315p. 
HÎNCU, M.; PETCU, L. C.; MEHEDINŢ, R.; MEHEDINŢ, T. Correlated histological and morphometric study of kidney and adrenal gland from Guinea pig exposed to hyperbaric-hyperoxic environment. Romanian Journal of Morphology and Embryology. v. 47, n. 1, p. 47-51, 2006.

IBAMA- Instituto Brasileiro do Meio Ambiente. Espécies ameaçadas. 2016. Disponível em: <http://www. ibama.gov.br>. Acesso em: 25 de março de 2016.

INTERNATIONAL COMMITTEE ON VETERINARY GROSS ANATOMICAL NOMENCLATURE. Nomina Anatomica Veterinaria. 5ed. Knoxville, 2012.

IUCN 2015. Red List of Threatened Species, version 2013.1 Available at www.iucnredlist.org. Access at November 2015.

KEMPNÁ, P.; FLÜCK, C. E. Adrenal gland development and defects. Best Practice \& Research Clinical Endocrinology \& Metabolism. v. 22, n. 1, p. 77-93, 2008. http://dx.doi.org/10.1016/j.beem.2007.07.008

KACZMARCZYK, D.; KMIEC, B.L. The cellular compositon of the adrenal medulla of sexually mature guinea pigs. Folia Morphologica. v. 63, n.1, p.75-78, 2004.

MACHADO, G. V.; ROMAGNOLLI, P.; SOUZA, J. R.; TURQUETI, V. S.; ULIANA, S. M.; SILVA, M. H. Arterial supply for to the adrenal glands of the nutria (Myocastor coypus Molina, 1782). Archives of Veterinary Science. v. 7, n. 2, p. 9-14, 2002. http://dx.doi.org/10.5380/avs.v7i2.3976

NEVES, W. C.; CAVALCANTE-FILHO, M. F.; CARVALHO, M. A. M.; MENEZES, D. J. A. Irrigação das glândulas adrenais em cutia dourada (Dasyprocta aguti). Revista FVZA, v. 14, n. 2, p. 165-174, 2007.

PARKER, V. J.; MENZIES, J. R. W.; DOUGLAS, A. J. Differential Changes in the Hypothalamic-PituitaryAdrenal Axis and Prolactin Responses to Stress in Early Pregnant Mice. Journal of Neuroendocrinology. v. 23, n. 11, p. 1066-1078, 2011. http://dx.doi.org/10.1111/j.1365-2826.2011.02204.x

PIGNATELLI, D.; PINTO, P.; MAGALHÃES, M. M.; MAGALHÃES, M. C. The development of the adrenal gland zona glomerulosa in the rat. A morphological, immunohistochemical and biochemical study. Molecular and Cellular Endocrinology. v. 140, p. 163-168, 1998. http://dx.doi.org/10.1016/S0303-7207(98)00045-8

QIU, S.; DU, Y.; WANG, L.; HU, C. Chromaffin cells of the adrenal gland in the beagle Dog. Anatomia, Histologia, Embriologia. v. 2, n. 234, p. 1-7, 2012.

REECE, W. O. Functional Anatomy and Physiology of Domestic Animals. 3ed. Baltmore: Lippincott Willians \& Wilkins, 2005. 513p.

RIBES, A. C.; MOHAMED, F.; DOMINGUEZ, S.; DELGADO, M.; SCARDAPANE, L.; GUZMAN, J.; PIEZZI, R. Probable effect of photoperiod on seasonal variation in the nuclear volume of the adrenal cortex of viscacha (Lagostomus maximus). Brazilian Journal of Medical and Biological Research, v. 32, n. 9, p. 11151120, 1999. http://dx.doi.org/10.1590/S0100-879X1999000900010

ROSA, L. A.; SILVA, F. O. C.; SANTOS, A. L. Q.; SILVA, D. C. O.; SANTOS, L. A.; LIZARDO, F. B. Origem e distribuição do nervo axilar em tamanduá-bandeira (Myrmecophaga tridactyla). Biotemas. v. 25, n. 3, p. 249-255, 2012. http://dx.doi.org/10.5007/2175-7925.2012v25n3p249

ROSSI, L. F.; LUACES, J. P.; ALDANA MARCOS, H. J.; CETICA, P. D.; PEREZ JIMENO, G.; MERANI, M. S. anatomy and histology of the male reproductive tract and spermatogenesis fine structure in the Lesser Anteater (Tamandua tetradactyla, Myrmecophagidae, Xenarthra): Morphological Evidences of Reproductive Functions. Anatomia, Histologia, Embryologia. v. 42, n. 4, p. 247-256, 2012. 
SAADI, L.; LEBAILI, N. Effect of a water-rich diet on adrenal zona glomerulosa in Gerbillus tarabuli. Comptes Rendus Biologies. v. 335, n. 1, p. 96-102, 2012. http://dx.doi.org/10.1016/j.crvi.2011.12.002

SANCHES, T. C.; MIRANDA, F. R.; OLIVEIRA, A. S.; MATUSHIMA, E. R. Hematology values of captive giant anteaters (Myrmecophaga tridactyla) and collared anteaters (Tamandua tetradactyla). Pesquisa Veternária Brasileira. v. 33, n. 4, p. 557-560, 2013. http://dx.doi.org/10.1590/S0100-736X2013000400022

SANTOS, A. C.; VIANA, D. C.; BERTASSOLI, B. M.; VASCONCELOS, B. G.; OLIVEIRA, D. M.; RICI, R. E. G.; OLIVEIRA, M. F.; MIGLINO, M. A.; ASSIS-NETO, A. C. Adrenal glands of Spix's yellow-toothed cavy (Galea spixii, Wagler, 1831): morphological and morphometric aspects. Brazilian Journal of Biology. v. 76, n. 03, p. 645-655, 2016. http://dx.doi.org/10.1590/1519-6984.23514

SHAW, C. A.; MCDONALD, H. G. First Record of Giant Anteater (Xenarthra, Myrmecophagidae) in North America. Science. v. 236, n. 4798, p. 186-188, 1987. http://dx.doi.org/10.1126/science.236.4798.186

SHINZAWA, K.; ISHIBASHI, S.; MURAKISHI, M.; WATANABE, K.; KOMINAMI, S.; KAWAHARA, A.; TAKEMORI, S. Relationship between zonal distribution of microsomal cytochrome P450s (P450 17-alfa, lyase and P450c21) and steroidogenic activities in guinea-pig adrenal cortex. Journal of Endocrinology. v. 191, n. 1, p. 191-200, 1988. http://dx.doi.org/10.1677/joe.0.1190191

van WEERDEN, W. M.; BIERINGS, H. G.; van STEENBRUGGE, G. J.; DE JONG, F. H.; SCHRÖDER, F. H. Adrenal glands of mouse and rat do not synthesize androgens. Life Sciences. v. 50, n. 12, p. 857-861, 1992. http://dx.doi.org/10.1016/0024-3205(92)90204-3

WHITLEY, R. J.; MEIKLE, W. A.; WATTS, N. B. Biogenic amines; Adrenocortical steroids In: BURTIS, C. A.; ASHWOOD, E. R. Tietz Textbook of Clinical Chemistry. 2ed. Philadelphia: W. B. Saunders Company, 1994. 2326p. 